\title{
Asymmetries in the euro area and TFP growth: evidence from three major European economies
}

\author{
Alessandro Bellocchi, Edgar Sanchez Carrera and \\ Giuseppe Travaglini \\ Dipartimento di Economia Società Politica, Università di Urbino Carlo Bo, Urbino, Italy
}

Asymmetries in the euro area and TFP growth

\section{Abstract}

Purpose - In this paper, the authors study the long-run determinants of total factor productivity (TFP) in three major European economies over the period 1983-2017, namely Germany, France and Italy.

Design/methodology/approach - The authors focus on the capital misallocation effects, scale effects and labor misallocation effects. To this end, the authors study how real interest rate shocks, real exchange rate shocks, real wage shocks and changes in labor regulation affected TFP in major European countries over the last decades. The authors employ a theoretical and an empirical model to investigate the issue. The empirical results are obtained using a VAR model for estimation.

Findings - A stripped-down model of labor market in open economy with technology progress allows to identify the relevant variables affecting TFP. On the empirical ground, the authors find a positive relationship between TFP and real interest rate in the long run. Importantly, the authors detect a positive relationship between TFP and real exchange rate. Further, the authors show that the TFP can respond positively to a stricter labor market regulation and to a higher real compensation per employee. The results provide support to the idea that TFP has a positive relation with prices in the long run, while it may be biased along the cycle because of price rigidity.

Research limitations/implications - The present model is stylized and may not capture all of the details of reality. The analysis should be extended to a larger number of countries. Technology progress could be proxied using different variables, as the R\&D expenditure or the number of patents. Micro data, for specific sectors and industries, can improve the quality of the empirical investigation.

Practical implications - Mainly the authors find that TFP has a positive relationship with price changes in the long run, while it may be biased along the cycle because of price stickiness. Capital misallocation and labor misallocation can negatively affect TFP. Thus, the observed divergences in European TFP can be traced back to the misallocation effects attributable to the decrease of real interest rate and real wages, together with the raising labor flexibility. Mainly, the authors detect a positive long-run relationship between TFP and real exchange rate. This outcome strengthens the supply-side view of the relationship between productivity and real exchange rate. Social implications - The authors believe that the present setup can be helpful to reflect critically on the nodes at the core of the productivity slowdown and asymmetries in the eurozone. The aim is to implement renewed policies in order to favor economic growth, convergence and stability in the euro area.

Originality/value - This research addresses the issue of asymmetries among European economies by focusing on the role played by real prices in the long run. Traditionally, the dynamics of TFP have been attributed only to technological components, human capital and knowledge. This work shows that the dynamics of prices such as the real interest rate, the real exchange rate and the real wage can also influence the technological process by pushing the production system toward choices that are not always optimal for economic growth. An interesting result of this research concerns the positive relationship between real exchange rates and TFP in the long term, evidence of an important supply-side effect on the technological process.

Keywords European asymmetries, TFP, Interest rate, Exchange rate, Labor market, Wage rate

Paper type Research paper

\section{JEL Classification - C22, D21, D24}

(C) Alessandro Bellocchi, Edgar Sanchez Carrera and Giuseppe Travaglini. Published by Emerald Publishing Limited. This article is published under the Creative Commons Attribution (CC BY 4.0) licence. Anyone may reproduce, distribute, translate and create derivative works of this article (for both commercial and non-commercial purposes), subject to full attribution to the original publication and authors. The full terms of this licence may be seen at http://creativecommons.org/licences/by/4.0/ legalcode 
JES

48,5

946

\section{Introduction}

Total factor productivity (TFP) is the exogenous residual that results from deducting the contribution of inputs to output growth (Solow, 1957). In traditional macroeconomic models, it proxies the technological content of productivity. Different variables come into play when explaining TFP. Traditionally, innovation, human capital and knowledge are the driving forces of TFP and the main engines of economic growth (Romer, 1994). Still, a shared theory of TFP does not exist. TFP may be affected by market imperfections. Azariadis and Kaas (2016) shows, for example, that with imperfect capital markets, TFP performs well when equities are owned by productive firms. Similarly, Kaas (2016) argues that a long-run equilibrium can be characterized by the coexistence of low real interest rate and TFP because the less efficient firms succeed in surviving at the lower capital cost. But more recently, Capasso et al. (2019) showed that, contrary to simplistic predictions, the real exchange rate can cause the real interest rate in an asymmetric way. This adverse combination can eventually result in capital misallocation. Accordingly, Cette et al. (2016) assert that the decreasing pattern of the real interest rates in Europe, from 1995 to 2008, explains the pre-great slowdown in productivity of the continental European economies. In their view, the decrease of the interest rates until 2008 contributed to cutting the user cost of capital, allowing the less competitive firms to keep producing. Thus "if resources are shifting toward lower marginal product uses, then misallocation can get worse and aggregate TFP could fall" (Cette et al., 2016, p. 10).

The present study focuses on these controversial issues. We study the long-run determinants of TFP in three major European economies over the period 1983-2017, namely Germany, France and Italy. Specifically, we test if changes in prices can give rise to asymmetries in TFP among European countries because of the misallocation of capital and labor. Traditionally, asymmetries may be caused by monetary shocks in interest and exchange rates (Lane, 2006). Further, the recent literature has stressed the relationship between TFP and labor market regulation. Mainly, labor deregulation has been criticized for the following reason: by reducing the hiring and firing costs of labor, it may encourage firms to postpone investment and innovation, resulting in the long-run fall of capital intensity and productivity (Gordon and Drew-Becker, 2008; Saltari and Travaglini, 2006, 2009; Pessoa and Van Rinen, 2014; Calcagnini et al., 2018).

Accordingly, we study the effects of changes in monetary and institutional variables on the TFP of three major European countries. There is a large disputed literature on this issue. Among these studies, the most recent references to our paper are Cette et al. (2016), Gopinath et al. (2017) and Bagnai and Mongeau-Ospina (2017).

We have already pointed out the contribution by Cette $e t$ al. (2016). Let us briefly reassume the other two papers. Gopinath et al. (2017) illustrate how the decrease in the real interest rate led, in recent years, to a significant decline in sectorial TFP of European countries. In response to the interest rate decrease, capital was misallocated toward firms with lower productive performance, but with higher market value. Accordingly, Bagnai and Mongeau-Ospina (2018) argue that changes in the real interest rate may affect labor productivity. However, they sustain that changes in the real exchange rate have a negative impact on labor productivity.

In what follows we discuss these findings. To this aim we present a stripped-down model of the labor market with technological progress, real exchange rate and labor regulation. Then, we employ a linearized version of it to estimate a vector autoregressive model (VAR) model and test its predictions. Mainly, and in contrast with a part of the literature, we find a positive long-run relationship between TFP and real exchange rate. Furthermore, TFP responds positively to a stricter labor market regulation, to a higher real wage and to a higher real interest rate. Therefore, our evidence shows that TFP has a positive relationship with prices in the long run, while it may be biased transitory along the cycle (negative effects) because of price rigidity and labor market stickiness. 
The paper is organized as follows. Section 2 offers a brief literature review. Section 3 develops a basic model of the labor market and TFP determinants. Section 4 presents stylized facts and the database. Section 5 develops the econometric framework with the empirical results. Section 6 concludes.
Asymmetries in the euro area and TFP growth

\section{Literature}

In the last two decades, TFP has been slowing down in European countries. Many recent contributions focus on these crucial issues.

At sectorial level, Melitz (2003) shows that productivity differences provide useful information about the heterogeneity of industries. He argues that the existence of persistent performance differences among similar firms (and countries) is well established so that the most recent studies in trade, industry and productivity have increasingly taken this stylized fact as a fundamental starting point. However, the question of what causes these differences is still an open question. Accordingly, Syverson (2011) analyzes the large differences in productivity within industries. He interprets productivity as a heterogeneous input of production crucially affected by differences in management practice, a higher quality of labor and capital, differential investment in ICT.

At country level, Gordon and Dew-Becker (2008) and Saltari and Travaglini (2009) study the relationship between productivity, capital accumulation and technology progress. Mainly, they address the question of whether labor supply shifts are the only source of the productivity slowdown among the main industrialized countries, over the last decades. It would imply that labor demand shifts are irrelevant to explain the labor-productivity tradeoff. Using a simple model of labor market, they show that the poor economic performance of many European countries can be accounted for by a combination of two shocks: an adverse technology shock to the labor demand and a positive nontechnology shock to the labor supply resulting from changes in institutions. In brief, while technology shocks can explain the productivity slowdown, but not the changes in employment, nontechnology shocks can capture changes of employment, but not the slowdown of productivity. Therefore, both shocks are necessary to provide a complete picture of the relationship between productivity and employment.

This issue has been recently studied by Pessoa and Van Reenen (2014). For the British economy, they find that the fall of labor productivity since 2008 is likely due to the decrease in capital intensity. This occurred because of the fall in real wages as a consequence of labor market deregulation. Accordingly, Cacciatore and Fiori (2016) analyze the macroeconomic effects of deregulating the goods and labor markets by means of endogenous product creation and labor market frictions in an otherwise standard real business cycle model. They find that (de)regulation affects producer entry costs, firing restrictions and unemployment benefits, with short-run recessionary effects, despite being expansionary in the long run.

A further strand of research pivots on the pattern of real interest rates to explain how their decrease, prior to the economic crisis of 2008, influenced the slowdown in productivity of continental European economies. As said earlier, Cette et al. (2016) focus on this issue. They sustain that the falling real interest rates and the sluggish ICT diffusion in the southern European countries were the consequences of the economic convergence started with the monetary union. Precisely, they pointed out that the monetary union and ICT diffusion required a deregulation of labor and product markets that inhibited the development of more efficient technologies causing the slowdown in TFP.

Accordingly, Gopinath et al. (2017) observe that, from early 1990s, countries in southern Europe experienced low productivity growth alongside declining real interest rates. Using data from manufacturing sector in Spain, they illustrate how the decline in the real interest rate, often attributed to the euro convergence process, leads to a significant decline in sectorial 
JES

48,5

948

TFP as capital inflows are misallocated toward firms that have a higher net worth, but are not necessarily more productive. They also observe similar trends in dispersion and productivity losses in Italy and Portugal, but not in Germany, France and Norway, thereby establishing an asymmetry between northern and southern European economies.

In this vein, Bagnai and Mongeau-Ospina (2017) study the productivity slowdown in the euro area using panel data by industrial sectors, concluding that the monetary unification has fostered divergences in productivity trends. Apparently, they detect the presence of real and financing sources of potential divergence in labor productivity with a crucial and negative role played by the real exchange rate.

To summarize, the current literature identifies at least three sources of shocks that may contribute to explain the observed productivity and TFP asymmetries among the major European countries. Specifically, we refer to:

Capital misallocation. It states that a decreasing real interest rate can incentivize firms to postpone investment and innovation, undermining TFP in the long run. Recent TFP slowdown in southern European countries can be explained by capital misallocation, with its aggregate effect on the single economies (Reis, 2013; Benigno and Fornaro, 2014; Cette et al., 2016; Gopinath et al., 2017);

Scale effect. It has two declinations. On the one hand, the "scale effect" is referable to the demand-side view of the real exchange rate appreciation (depreciation) on TFP. Precisely, it captures the role of the real exchange rate in affecting external demand and productivity growth (Verdoon, 1949; Kaldor, 1966). Accordingly, an overvalued (devaluated) currency may reduce (increase) the scale of production and the aggregate demand of an economy negatively (positively) affecting the productivity growth (Ostry, 1998; Rodrick, 2008). This relationship varies across sectors and countries, depending on the structure of the economy and the competitiveness degree of its markets (Tomlin and Fung, 2010). On the other hand, the supply-side view stresses the positive and long-lasting consequences of a real exchange rate appreciation on productivity and TFP. Precisely, it implies that a "hard" real exchange rate may contribute to raise productivity and competitiveness in the long run (Porter, 1990) by forcing innovation and technology progress in tradeable sectors.

Labor misallocation. It focuses on the role of labor market regulation in affecting investment, innovation and TFP (Bassanini et al., 2009; Calcagnini et al., 2018). The current debate identifies at least two main opposite effects. On the one hand, labor regulation may increase the firms' labor and investment adjustment costs decreasing innovation and investment (Bentolila and Bertola, 1990; Layard et al., 1997; Nickell and Layard, 1999; Bartelsman et al., 2016). On the other hand, a stricter labor regulation may stimulate firms to invest and innovate to recover rents, positively affecting TFP in the long run (Acemoglu, 1998; Blanchard and Wolfers, 2000; Griffith and Macartney, 2014; Pessoa and Van Reenen, 2014). We will focus on these contrasting sources to study how TFP growth responds to changes in labor market regulation and real compensation.

We present a simple labor market model in open economy with TFP and regulation. The model is only illustrative, but nevertheless it represents a useful device to discuss our interpretation. Then, we develop a VAR model for three major European countries, namely France, Germany and Italy, over the period 1983-2017. The long-run relationships between TFP, real interest rate, real exchange rate, labor market regulation and real wage are studied. Our most important result is to show that, in some relevant cases, an increase in real exchange rate and real interest rate can cause a persistent increase in TFP.

\section{The model}

We use a basic labor market model in open economy to explain our view. It builds on Layard et al. (1997), Blanchard (2013) and Carlin and Soskice (2014). 
We start with the price-setting rule. The existence of a markup over the unit labor cost implies that the (real) productivity $a$ is greater than the marginal cost $\frac{W^{P S}}{P}$ by a factor equal to the markup, that is,

$$
a=\frac{W^{P S}}{P}\left(1+\mu \frac{r}{1+z}\right)
$$

As in Layard et al. (1997), the markup $\left(1+\mu \frac{r}{1+z}\right)$ tends to raise with the level of activity, proxied by the real interest rate $r$. To this component we add the effects of labor market regulation, measured by the catchall variable $z \geq 0$. Specifically, we assume that the bargaining power of trade unions tends to redistribute a share of the rents to workers by reducing the market power of firms and their corresponding markup. The variable $z$ captures these redistributive actions by countering the expansive effects caused by the increasing level of activities.

Then, the prices $P$ of national goods are set as a markup on nominal wage $W^{P S}$ (the firms are willing to pay) measured in effective units

$$
P=\left(1+\mu \frac{r}{1+z}\right) \frac{W^{P S}}{a}
$$

Equation (2) states that each worker produces $a$ units of output. Put another way, producing one unit of output requires $\frac{1}{a}$ workers. If the nominal wage is equal to $W^{P S}$, the nominal cost of producing one unit of output is therefore equal to $\frac{W^{P S}}{a}$. Thus, an increase in productivity decreases costs, which reduces the price level of national goods, given the nominal wage the setters are willing to pay. We employ TFP to proxy $a$, the measure of productivity.

In an open economy, workers consume both domestic and foreign goods in some proportion. Real wages depend on a composite price index $P_{c}$, which includes prices of those domestic and foreign goods. Foreign goods have price $P^{*}$, while domestic goods have price $P$. The share of the foreign goods on total consumption is $\gamma \in(0,1)$. Hence, the consumer price index can be written as

$$
P_{c}=(1-\gamma) P+\gamma \frac{P^{*}}{E}
$$

where $E$ is the nominal exchange rate defined as the price of the domestic currency in terms of the foreign currency. An increase (decrease) in the nominal exchange rate $E$ is an appreciation (depreciation) of the domestic currency in terms of a foreign currency. Let's define the real exchange rate as $e=\frac{\mathrm{EP}}{P^{*}}$. Substituting (2) in (3), using the approximation that $\frac{1}{1+x} \cong 1-x$, and solving for the real wage $w^{\mathrm{ps}} \equiv W^{P S} / P_{c}$ we get

$$
w^{p s}=\frac{a\left(1-\mu \frac{r}{1+z}\right)}{1+\gamma\left(e^{-1}-1\right)}
$$

where $w^{\mathrm{ps}}$ is the real wage that the price setters are willing to pay. This can be approximated by

So that the relation between $w$ and $e$ is

$$
w^{\mathrm{ps}} \cong a\left(1-\mu \frac{r}{1+z}\right)\left[1-\gamma\left(e^{-1}-1\right)\right]
$$

$$
\frac{d w^{P S}}{d e} \cong a\left(1-\mu \frac{r}{1+z}\right) \gamma e^{-2}>0
$$

Asymmetries in the euro area and TFP growth

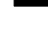


JES

48,5

950

The price-setting rule implies that the real wage $w^{\mathrm{ps}}$, the firms are willing to pay, is positively related to the real exchange rate $e$. Indeed, if imported goods become more expensive - that is, if $e$ decreases, because either the foreign price $P^{*}$ increases or the nominal exchange rate $E$ depreciates - consumption bundles become more expensive, reducing the real wage of workers. Thus, given the price of imports and the nominal exchange rate, the price to consumers varies with the real exchange rate.

Turn to the wage setting. A decrease of the unemployment rate $u$, and a stricter labor market regulation - measured by the catchall variable $z$, is associated with a raise in the nominal wage demanded by workers (Blanchard, 2013). Further, in an open economy, under the assumption of Nash bargaining in the labor market, the demanded nominal wage increases by a proportion $\lambda e$, where $0 \leq \lambda \leq 1$ denotes the relative bargaining strength of workers to defend the real wage. The evidence also suggests that, other things being equal, wages are typically set to reflect the increase in productivity $a$ over time. This suggests the following extension of the wage-setting rule

$$
W^{\mathrm{WS}}=P_{c}[z-\beta u+\lambda(e+a)]
$$

or

$$
w^{\mathrm{ws}}=z-\beta u+\lambda e+\lambda a
$$

where $w^{\mathrm{ws}} \equiv W^{\mathrm{ws}} / P_{c}$ is the real wage demanded by workers. Wages now depend on the level of both productivity and real exchange rate. If workers and firms both expect productivity and real exchange rate to change, they will incorporate those expectations into the wages set in bargaining. The equilibrium in the labor market requires that $w^{\mathrm{ps}}=w^{\mathrm{ws}}$. Then, solving for $a$ we get an endogenous relationship for the TFP in equilibrium

$$
a(u, e, r, z, \mu)=\frac{z-\beta u+\lambda e}{\left(1-\mu \frac{r}{1+z}\right)\left[1-\gamma\left(e^{-1}-1\right)\right]-\lambda}
$$

Equation (9) states that TFP tends to decrease as the unemployment rate $u$ increases and increase when the interest rate $r$ increases. Notice that capital misallocation can emerge when $r$ decreases steadily. Further, equation (7) also says that the markup component $\mu$ has a positive long-run impact on the TFP. We label this relation as a Schumpeterian effect because, as Schumpeter argued (1961), economic growth revolves around innovation, market power and entrepreneurial activities.

However, the relationship of TFP with the labor market regulation $z$ and the real exchange rate $e$ is much more controversial. It is formally captured by the derivatives

$$
\frac{d a}{d z} \frac{>}{<} 0 ; \quad \frac{d a}{d e} \frac{>}{<} 0
$$

According to (10), the sign of the derivatives depends on the values of the parameters that characterize the price-setting and the wage-setting rules. For example, a higher value of $\lambda$ compared to the share of foreign goods on total consumption $\gamma$, increases, in a bilateral negotiation, the average strength of firms to innovate for recovering productivity and competitiveness in the long run (Calcagnini et al., 2018). However, as said earlier, the level of productivity strictly depends on both technology and real exchange rate. Of course, the latter scale effect refers to the supply-side view of the real exchange rate. It means that an increase (decrease) in $e$ contributes to increase (decrease) in productivity, improving firms' competitiveness. This is actually an old idea that explains why a country would prefer a hard currency instead of a weak currency (Harris, 2001). Indeed, as Porter (1990) pointed out, 
depreciations can reduce productivity over time, whereas an overvalued real exchange rate can sometimes contribute to increased productivity and competitiveness by forcing innovation and technology progress in tradeable sectors [1]. Furthermore, note that analogous considerations can explain the ambiguous relationship between $a$ and the variable $z$.

To obtain estimates of equation (9), we study the fit of our model. The main question is: how well does it explain the observed patterns of TFP? To provide an answer, a linearized version of equation (9) is employed to run the empirical model.

Equation (9) gives some a priori about the causal relationships between the TFP and the explanatory variables. In the long run, the relationship between real interest rate and TFP is positive: an increase in $r$ tends to raise the level of $a$. Instead, the relationship with the real exchange rate $e$ and the labor regulation is ambiguous. Further, the price-setting rule (2) reveals the existence of a positive relationship between $a$ and $w$ (but also a reverse causation between them). Analogous algebraic sign has the Schumpeterian link between $a$ and the markup component $\mu$.

To resume, the main implication of our model is that a higher level of both real interest rate and real wage can push up TFP just as more innovation and investment can stimulate productivity in the standard neoclassical growth model. The two processes are strictly related. However, the impact of changes in the real exchange rate and labor regulation on the TFP remains ambiguous. Hence, in our model there are scenarios where lower interest rates and lower real wage can depress technological progress, slowing down productivity instead of increasing it in the long run.

\section{Database and stylized facts}

We are interested in studying the determinants of the TFP in the major three European countries, namely Germany, France, Italy. Data set relies on the European Commission AMECO database, over the period 1983-2017 [2]. Our data provides information on:

(1) TFP, $a$. It measures the difference between the contribution of the real output (GDP) and the capital intensity weighted by capital share. It is expressed as an index, with $2010=100$. TFP takes into account the impact of any technology factor switching the production function in the long run. In the empirical analysis we use the symbol a instead of TFP to simplify notation.

(2) Real long-term interest rates, $r$. It is a proxy of the user cost of capital and captures the effects of capital misallocation on TFP. As noted by Cette et al. (2016), a low real interest rate can allow the less competitive firms to survive in the market, reducing innovation and TFP in the long run. In our empirical model, the user cost is proxied by the ten-year nominal interest rate on long-term government bonds deflated using the price deflator of gross domestic product at market prices.

(3) Real effective exchange rate, $e$. It provides comparable measures of euro area countries' price and cost competitiveness. Its value depends on the nominal exchange rate and on the prices of national and foreign goods exchanged in the international markets. Thus, $e$ provides a measure of the performance of any single economy relative to the rest of the main European countries.

(4) Real compensation per employee, $w$. It captures the impact of labor cost on TFP. The AMECO database uses a domestic concept of real compensation, including residents as well as nonresidents working for resident producer units. Compensation includes not only wages and salaries, but also social contributions.
Asymmetries in the euro area and TFP growth 
JES

48,5

952

(5) Incidence of temporary employment (ITE) for young workers on total employment, $z$ [3]. It refers to standardized age group 15-24 of the OECD statistics and captures changes in labor market regulation [4]. Hence, $z$ provides a measure of the impact of changes in labor market regulation on TFP. Following Calcagnini et al. (2018), we assume that the higher the labor flexibility, the higher is the share of temporary workers employed in production by firms [5].

In Figure 1 variables under consideration are rescaled to have a mean of 0 and a standard deviation of 1 . Standardizing makes it easier to compare scores, even if those scores were measured on different scales, as it is in our analysis. It also makes it easier to read the results from impulse response function (IRF) and ensures that all variables contribute to a scale when added together.

Figure 1 shows the graphs of the variables under investigation and, for completeness, the one of the EPL index. The inspection of the figures provides information about their
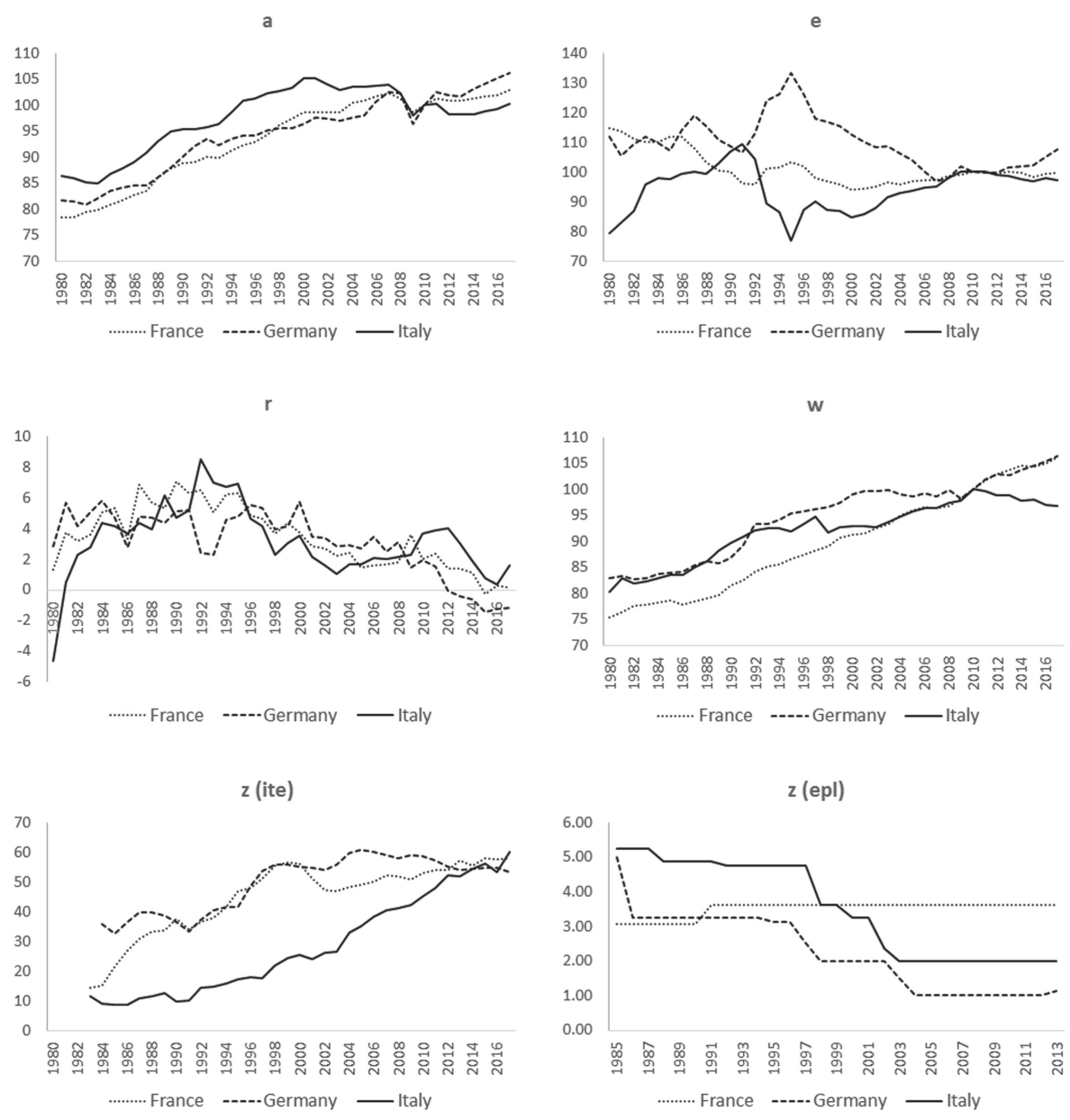

Figure 1.

Time series

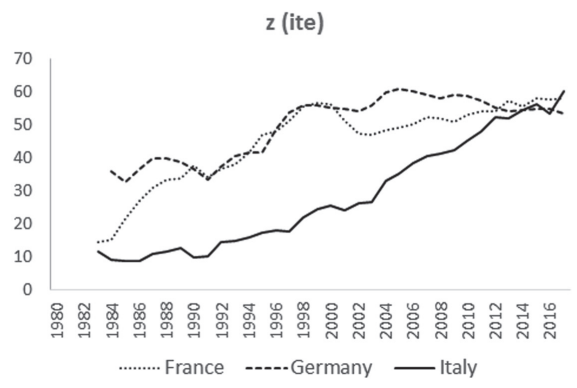

Source(s): AMECO database 
divergence or convergence over time in the three countries under investigation. Mainly, while Italy and France show a decreasing TFP path from the beginning of 2000, Germany shows an increasing path, even after the economic crisis of 2008. Notice that the real exchange rates follow an asymmetric path until 2010. They become more stable hereafter. Same asymmetries characterize the pattern of real wages, temporary employment (increasing in all countries) and savings. Only the real interest rates have a common trend although they exhibit an increasing volatility during the period 2008-2014.

\section{Estimation results}

In this section we present our VAR for the European economies under investigation, namely Germany, France and Italy. The impact of five shocks in TFP, index of temporary employment, real interest rate, real exchange rate and the real wage is analyzed. Further, we compare the observed responses of our variables, along time and among them, in order to check their consistency with the prediction of our theoretical model. Our approach is essentially empirical. We employ a VAR model without imposing any a priori restrictions. We only limit our analysis to decompose the VAR residuals in a triangular fashion, also known as Cholesky decomposition (Sims (1980); Cette et al., 2016; Calcagnini et al., 2018). However, given that we are interested in the response of TFP to some variables, we focus on the effects of shocks to TFP after allowing for contemporaneous and past shocks in the variables considered in our model. The ordering of the variables is done starting from those that we consider the (most) exogenous of the model, proceeding toward a growing endogeneity. For this reason, the ordering in the VAR starts with the index of labor market regulation, followed by the real interest rate and the real exchange rate, with lastly the real wage. This ordering constraints the TFP to respond to shocks with some lags. In contrast, the other variables respond immediately to the labor regulation (institutional effects) but not to the TFP shock (supply effect). From our empirical analysis, it emerges that the qualitative responses do not change with the change of the ordering and that the responses are similar across alternative treatments of the deterministic components.

The first step consists in estimating a basic VAR system, which includes the following variables for the period 1983-2017: TFP $(a)$, incidence of temporary employment $(z)$, real long-term interest rate $(r)$, real effective exchange rate $(e)$, real compensation per employee $(w)$.

Let $x$ be the data vector with dimension $5 \times 1$ for each period $t$ and $x=[a, z, r, e, w]^{\prime}$. The VAR model is

$$
x_{t}=c+T+B_{1} x_{t-1}+\ldots+B_{p} x_{t-p}+f_{t}
$$

where $f_{t}$ is a $5 \times 1$ vector of reduced-form shocks, $B_{p}$ is a $5 \times 5$ matrices of coefficients, $c$ is a $5 \times 1$ vector of intercepts and $T$ is a $5 \times 1$ vector of trends. Consistent estimates of the VAR parameters can be obtained by ordinary least squares. Then, we derive the IRFs showing the response of all variables to each reduced-form shock. To relate reduced-form to structural shocks, we assume that the structural model for $x_{t}$ is of the following form:

$$
A_{0} x_{t}=c^{\prime}+T^{\prime}+A_{1} x_{t-1}+\ldots+A_{p} x_{t-p}+g_{t}
$$

where $g_{t}$ is a five-dimensional vector of orthogonal structural shocks, $c$ is a vector of intercepts and $A_{p}$ are matrices of coefficients. Premultiplying (11) by $A_{0}$ and relating the resulting equation to (12), we obtain the following correspondence between the reduced-form and structural shocks

$$
A_{0} f_{t}=g_{t}
$$

Asymmetries in the euro area and TFP growth 
JES

48,5

954

There are several ways to recover the parameters in the structural form equations from the estimated parameters in the reduced form equation (12). A popular method is to orthogonalize the reduced-form disturbances by Cholesky decomposition imposing $n(n-1) / 2$ restrictions on the variance-covariance matrix (Sims, 1980). Cholesky decomposition is achieved by making restrictions on the $A_{0}$ matrix itself by imposing some of its elements to be zero, that is, by turning off some of the contemporaneous correlations between the different variables. Indeed, if $A_{0}$ is assumed to be lower triangular, then

$$
A_{0}^{-1}=\operatorname{chol}(\Omega)
$$

where $\operatorname{chol}(\Omega)$ denotes the Cholesky decomposition of the covariance matrix $\Omega$ of the residuals in the reduced-form VAR. These restrictions on the contemporaneous correlations of the errors are enough to recover unique estimates of the fundamental shocks from the VAR residuals. However, this triangular fashion implies the existence of a recursive structure. Precisely, we use the implications derived from our model to suppose that one variable has contemporaneous effect on the others. Consistently with our labor market model, we put first the most exogenous among our variables, then the second one and so on (i.e. TFP, real exchange rate, ITE, real compensation and the real interest rate). The last variable is the one for which all the other variables have effect on it.

\subsection{Impulse response functions}

We begin our empirical analysis estimating the unrestricted VAR system with one lag for each variable of the five equations, a constant and a time trend. A considerable amount of literature shows the advantages of using unrestricted VAR by examining IRFs in cointegrated systems (Naka and Tufte, 1997). In addition, a number of studies have shown that unrestricted VARs are superior in terms of forecast variance (Engle and Yoo, 1987; Clements and Hendry, 1995; Hoffman and Rasche, 1996).

A way to study the short and long-run responses of a VAR model is to compute its IRFs. The impulse responses trace out how the shocks in one of the variables impact on current and future values of the other variables in the model. Then, if the system of equations is stable, any time series tends to converge toward the (new) steady state after the initial shock.

The IRFs are built from inversion of the VAR model, via the Wald transformation to a moving average representation. The advantage of the IRFs is that they allow shock accounting. To run the procedure, we set all initial values to zero and shock one of the variables to a unit value at time zero. The response function indicates what happens to the system in succeeding periods if no further shocks occur. We use the Cholesky ordering as specified earlier.

The correct lag length selection is essential for VAR specification, having lags that are too short fails to capture the system's dynamics. Indeed, having too many lags causes a loss of degrees of freedom, resulting in overparameterization. Based on the minimized values of the respective information criteria (Akaike, the Bayesian criterion of Schwartz and HannanQuinn), we use one lag for each model. Then, IRFs and variance decompositions (VDCs) are computed. The solid line in Figure 2-7 describes the impulse response of any single variable to an initial one-standard deviation shock. Shaded area represents the $90 \%$ bootstrap confidence interval around the point estimates. The errors of the IRFs are computed by simulation using 1,000 replications of the model, and the shaded area equals the point estimates of the IRF plus or minus 1.645 times the simulated standard error. The horizon is given on the horizontal axis. The computed IRFs provide outcomes coherent with the structure of our theoretical model.

5.1.1 Responses of TFP to shocks. The response of TFP to shocks is the main issue of our analysis. According to the theoretical model, we expect to find a positive relationship among 
Asymmetries in the euro area and TFP growth
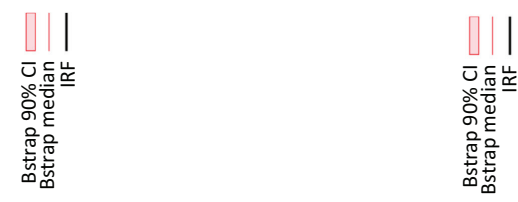

955
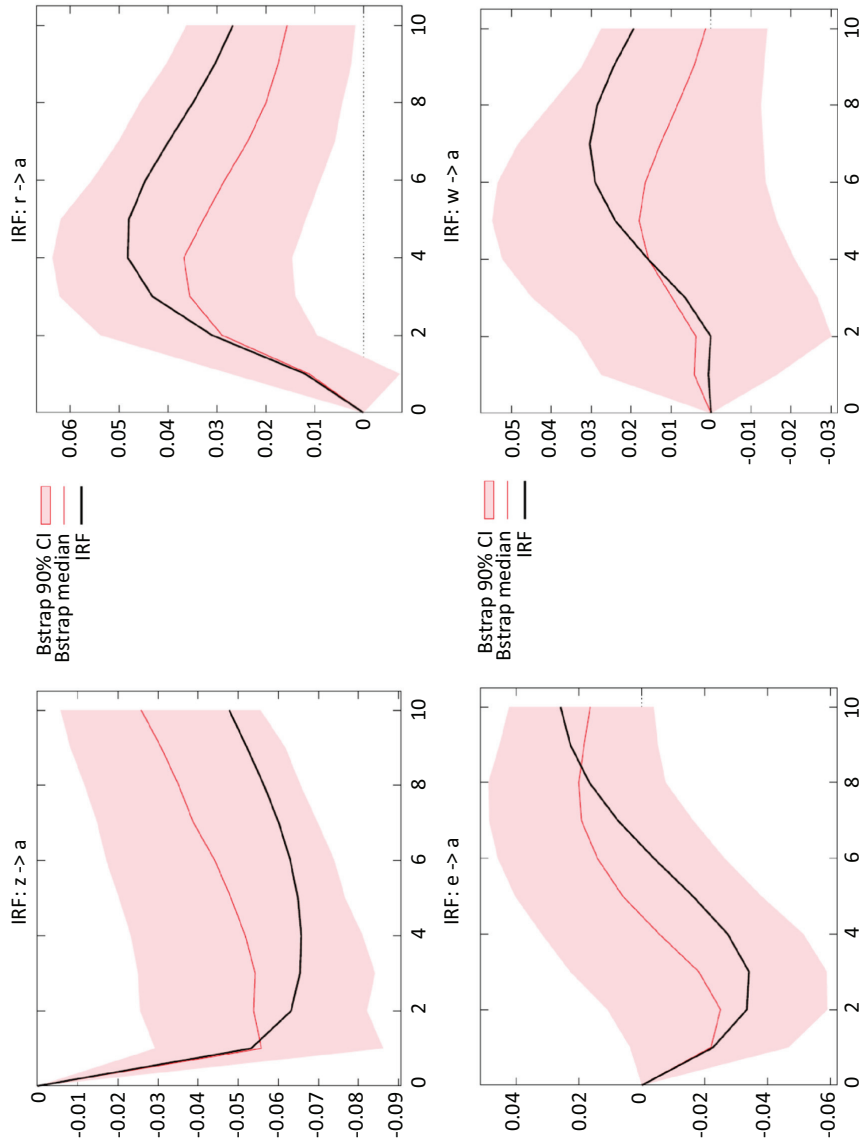

Figure 2. Italy: TFP responses to shocks 
JES

48,5

956
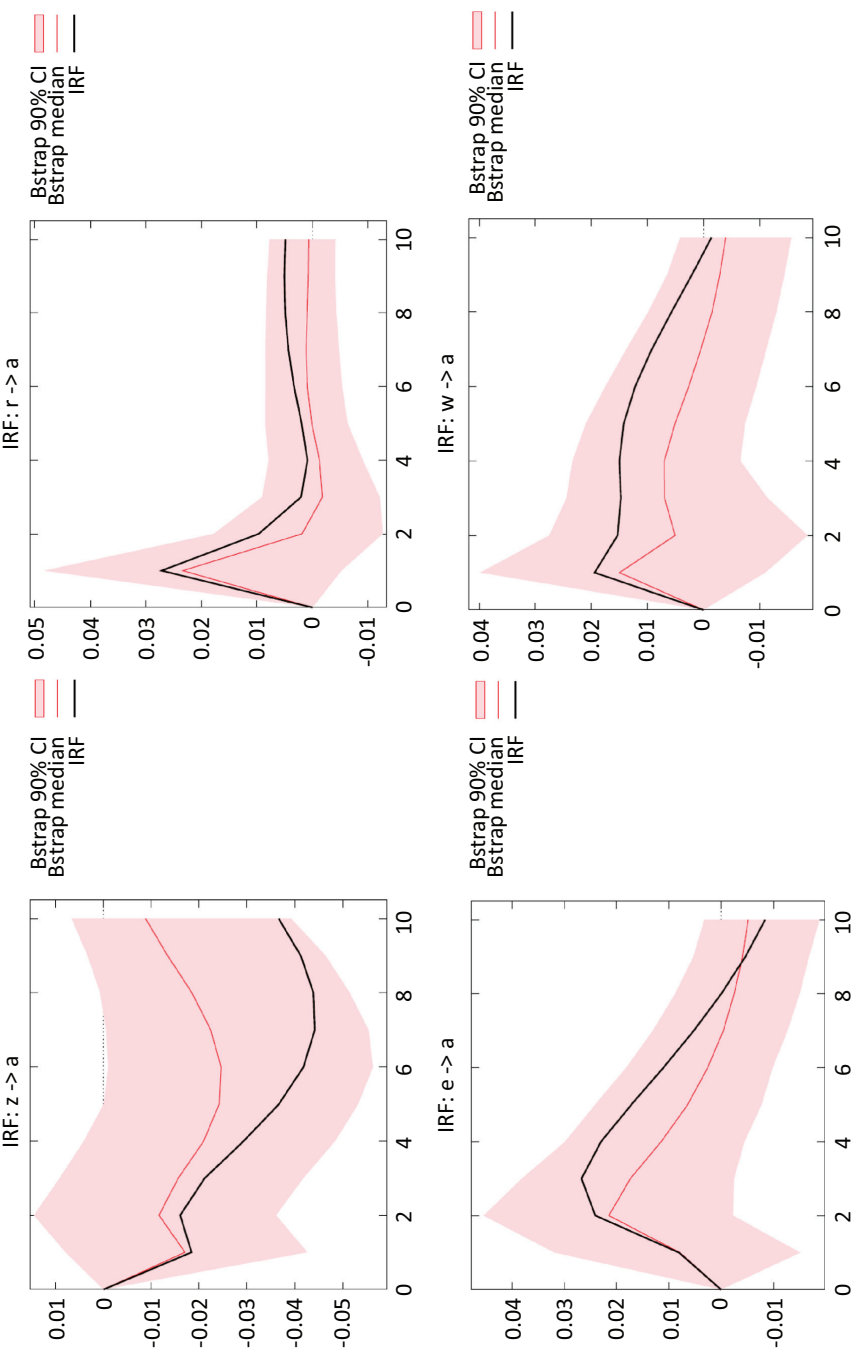

Figure 3.

Germany: TFP

responses to shocks 
Asymmetries in the euro area and TFP growth
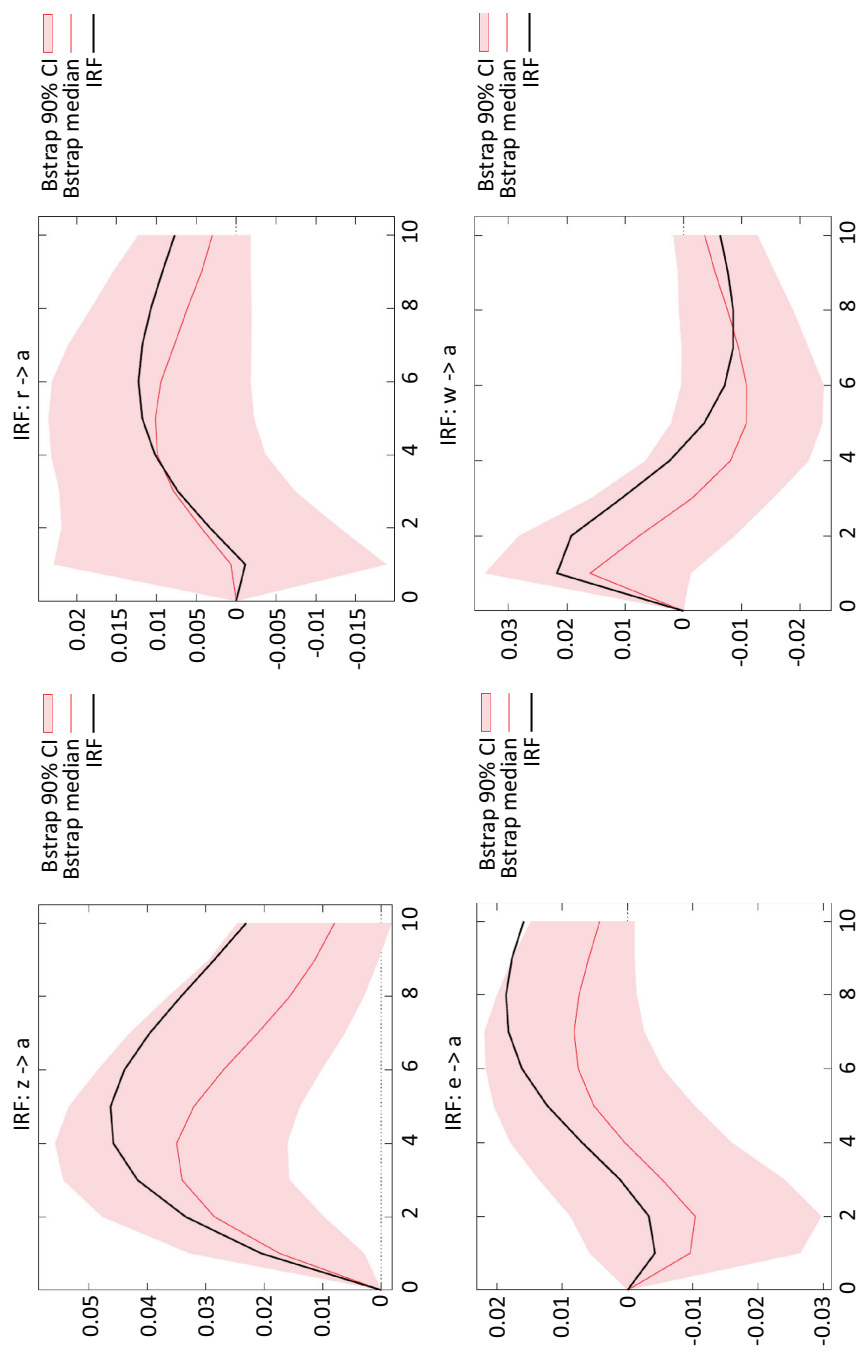

Figure 4. 
JES

48,5

958
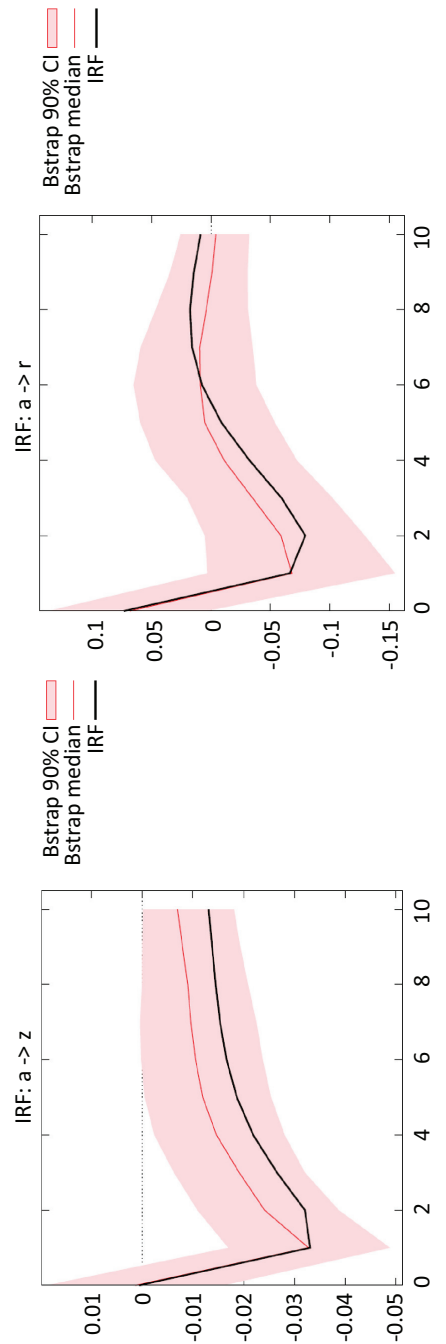
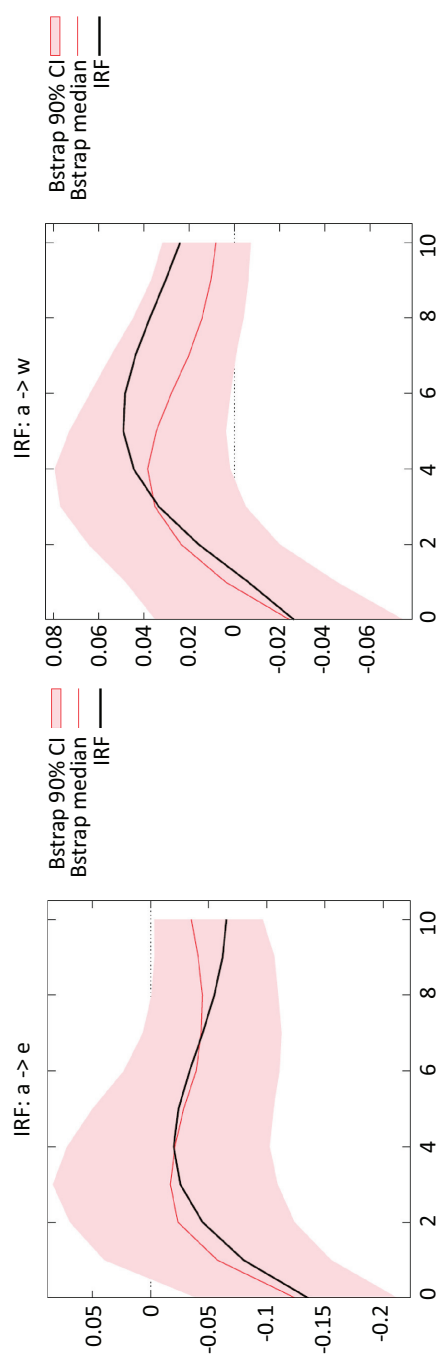

Figure 5.

Italy: Responses to a TFP shock 
Asymmetries in the euro area and TFP growth
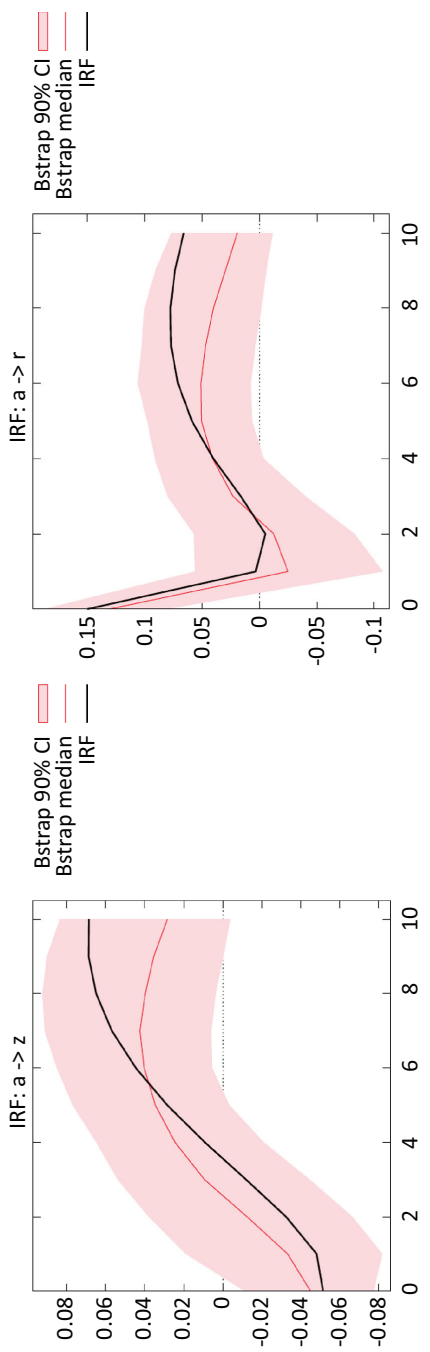
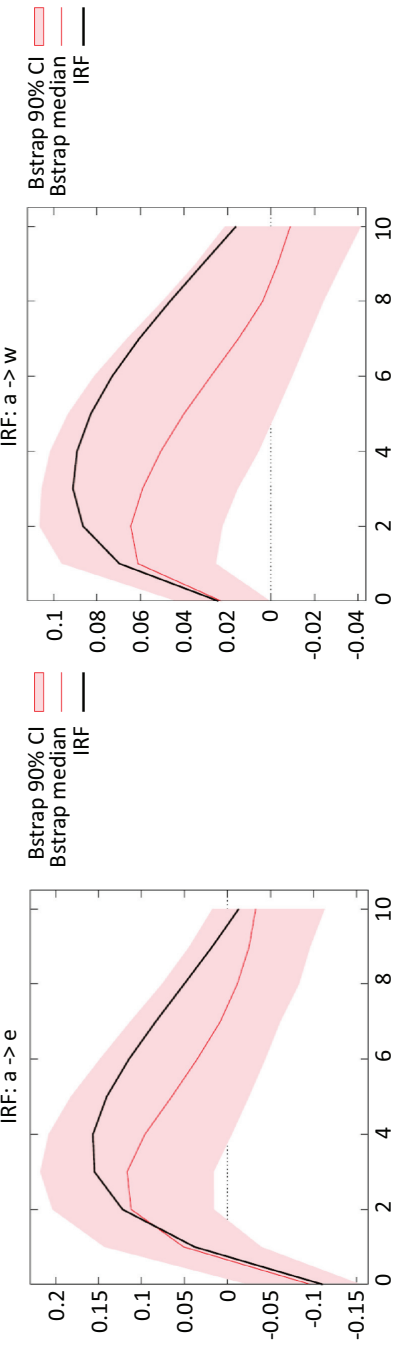

959

Figure 6. 
JES

48,5

960
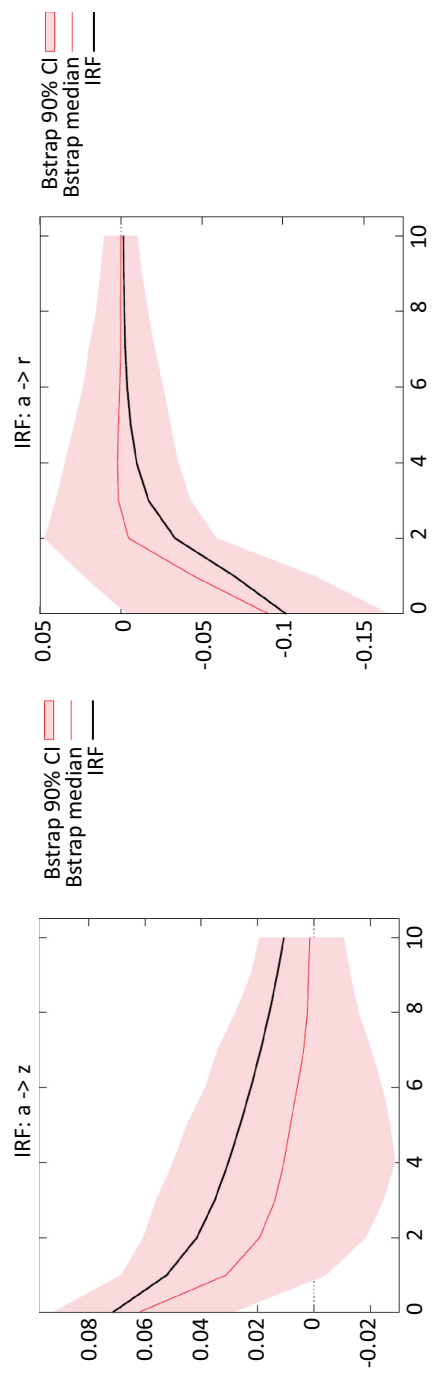
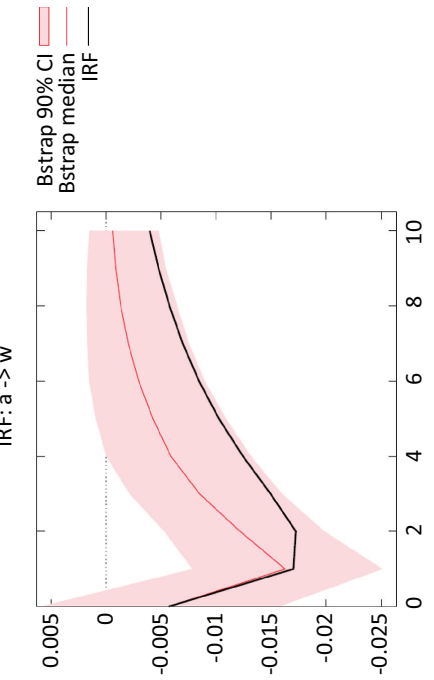

$\square||$

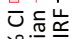

จิํํำ

कू

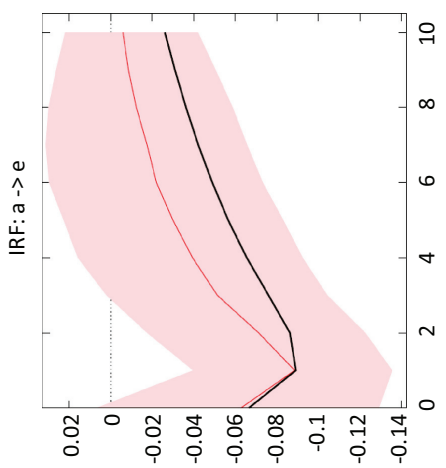

Figure 7.

France: Responses to a TFP shock 
TFP, interest rate $r$ and real wage $w$. Again, evidences on the relationship between $e, z$ and $a$, could be mixed since the response of TFP to shocks in $e$ and $z$ depends on the magnitude of the parameters that characterize the price-setting and the wage-setting rules. The IRFs of TFP to shocks are shown in Figure 2-4.

From the IRFs it emerges that in Italy and Germany, the TFP reacts positively to shocks in real wages and labor regulation, in the short and long run (labor misallocation). This implies that when these shocks take place, the value of productivity tends to increase, positively affecting the economic growth. For Italy, we find that the responses of $a$ to a real wage shock is negligible in the short run, then gradually increases with a full positive response in about five years. TFP response to this shock is greater and more immediate in Germany, although the initial expansive impact declines to vanish after about five years. The response of France to these shocks, on the other hand, is noteworthy. TFP responds positively to the increasing flexibility of labor. Similarly, the increase in productivity, in response to a shock in real wage, turns into a negative change in the medium and long run. While for labor market regulation, the effect is always significant at all frequencies, for real wages it turns out to be only slightly significant in Italy and Germany.

Figures also shed interesting light on the relationship between changes in real interest rates and TFP. According to our analysis, these two variables are positively correlated in the three economies (misallocation effect). Only France experiences a slight negative initial response probably due to real and nominal rigidities in the short run. In the intervening periods, real interest rate and TFP have the same positive sign. In this case, the response is nonsignificant for the first four years, but it becomes significant after $6-8$ years. This implies uncertainty on the sign of the conditional correlation in the short run, but this indeterminacy tends to disappear in the long run.

Then, for Italy and France, the responses of productivity to a change in the real exchange rate $e$ are suggestive of the presence of a $J$-curve for productivity. Indeed, TFP decreases in the short run, but the positive effects of an increase in $e$ on productivity are largely over by about 3-6 years. Thus, the IRFs capture both the demand and supply effects of the real exchange rate on the competitiveness and productivity growth of the two economies (scale effects). Opposite is the German response. It shows a short-run increase in productivity, in response to an increase in the real exchange rate. However, this expansionary effect vanishes over time, until it becomes slightly negative as time passes, even if it is not very significant in the long run.

The qualitative results are similar across all alternative specifications and time trends. The main significant difference appears in the initial TFP response of France to a change in labor market rigidity: in the case when time trend is not included, the response is initially negative rather than positive as in the presented case.

5.1.2 Reverse causation. Figures 5-7 illustrate the responses of $z, r, e$ and $w$ to a shock in $a$ (TFP). We estimate a global negative impact of a TFP shock on the real exchange rate $e$ (this means an improvement in international competitiveness). In France and Italy, the impact tends to be globally negative. Contrariwise, in Germany, the shock has an initial negative impact on the real exchange rate. Then, it reverses to return negative only in the long run. The response of Germany is always significant, while, for instance, the negative effect of TFP in Italy in the short run is not until close to six years when it becomes (and then remain) significant for the last two two years of the simulation. On the contrary in France, the significance is higher in the short run and fades away with higher frequencies. Much more heterogeneous is the impact of technological progress on the labor market, as it is measured by the $z$ index. In Italy, the value of $z$ decreases steadily, that is, the share of temporary workers compared to permanent workers decreases, signaling an improvement in the composition of the labor market. In Germany, the initial negative effect becomes positive over time. In France, as already seen, the impact is on the whole positive with a permanent increase
Asymmetries in the euro area and TFP growth

961 
JES

48,5

962

in the share of temporary workers compared to the stable ones. Therefore, the response of the three economies to a change in technology is different in each of them, with important consequences for the policies of convergence and synchronization of the European economies. It is worth pointing out that in this case (except for France in the long run), all the IRFs are very significant.

A certain heterogeneity also emerges for the response of the real wage $w$ to a technological shock. In Italy and Germany, real wages increase in the long run. While in the former case, the response becomes significant as the years go by, the latter one has a short-run significance that is lost in the long run. In France, real wage tends to decrease, even if the actual size of this slowdown is negligible but significant. The responses are consistent with the recomposition of the labor markets, which, as seen earlier, favors stable employment in both Italy and Germany, favoring temporary positions in France.

Finally, the real interest rate $r$ responses to a TFP shock are heterogeneous. In France, the real interest rate decreases at all frequencies. It increases in Italy and Germany where after an initial negative response, it increases in the long run (even if in the case of Italy with little significance).

To resume, our empirical findings confirm the existence of some asymmetries in the major European countries. Capital and labor misallocation can explain this diverging process in the three economies under consideration. Note however that, for the three economies under analysis, the long-run elasticity between TFP and real exchange rate $e$ is essentially positive.

What emerges from our analysis? Firstly, a positive relationship between TFP and real exchange rate can exist and characterize the European economic growth. These dynamic effects are consistent with a supply-side view of the effects of real exchange rate on technological progress and productivity, in which changes in real exchange rate build up in the long run until the adjustment of investment and innovation leads the economy toward the new equilibrium. Hence, technological progress and productivity are not necessarily displaced by a hard real exchange rate, as the demand-side view of the appreciation of the real exchange rate states (Verdoon, 1949). Mainly, our evidence provides some new support for the real exchange rate supply-side view that an overvalued exchange rate can contribute to improve productivity, rather than reduce it, by forcing technological progress and innovation in the long run (Porter, 1990).

Also note from our VAR model results that, in Italy and Germany, the long-run elasticity between labor market deregulation and TFP is negative and around $-0.5 \%$ in the long run. This elasticity is, however, positive for France. This latter result has a crucial implication. It suggests that labor market reforms may have adverse and unexpected impacts on technology progress and productivity growth. This happens because, in some scenario, a more flexible labor market can reduce the incentive of firms to invest and innovate slowing down competitiveness and profitability in the long run. Obviously, the magnitude of these effects depends on the heterogeneity of the productive and institutional structures of each single economy, as it is in the case of the European community.

Therefore, our analysis helps to cast some critical light on the optimistic view that more flexible labor markets, on the one hand, and weaker real exchange rates, on the other, are necessary preconditions for boosting European productivity and economic growth. As we have shown, there are theoretical reasons and empirical results showing how the complex economic reality of the major European economies can give rise to unexpected consequences. It is necessary to take due account of the heterogeneity and divergence of the European economies in order to build a stable and growing path of community development.

5.1.3 Forecast error variance decomposition. While the IRFs trace the effects of shocks to one variable on other variables with time, the forecast error variance decomposition (FEVD) technique measures the proportion of forecast error variance in one variable explained by shocks in itself and the other variables at various horizons. 
To identify shocks in each of the variables, and the dynamic responses to such shocks, the variance-covariance matrix of the VAR is factorized using the previous Cholesky decomposition. The results of the FEVD at various periods, generated by the five variables of the reduced VAR model, are reported in Tables 1-3. Usually, own series shocks explain most of the error variance of each variable. However, the shock will also affect other variables in the system. From our decomposition, we get four main results.

First, as expected, the decomposition shows that the percentage of TFP variance explained by its own shock is initially high but declines after a ten-year horizon, to about $75 \%$ in Germany and $70 \%$ in Italy. Similarly, in France, after the initial step, the TFP variance tends to fall converging toward the average value $72 \%$ after ten years. It is worth noting that the proportion of variance attributable to the TFP shocks decreases as the horizon lengthens. This implies that the TFP is highly endogenous, with the remaining variables accounting for the residual volatility in TFP to various degrees.

Second, in France and Italy, an important role, in explaining TFP volatility, is played by shocks in $z$ (changes in labor market regulation), which accounts for respectively 22 and $17 \%$ of the total TFP variance in the long run. On the contrary, in Germany, this shock has a limited impact on variance where the total proportion of TFP volatility is steadily below $14 \%$.

Third, the effect of shocks to the interest rate $r$ on the TFP is quite negligible in France (where it explains at most $1 \%$ of the TFP variance after ten years) and limited in Germany (with a contribution of $2 \%$ ). Conversely, it is more consistent in Italy where at the end of the periods the proportion of error variance increases at $8 \%$.

Then, in Germany, the TFP variance is in part explained by the variations in the real exchange rate $e(5 \%)$, while in the remaining two countries this effect is even minor $(4 \%$ in Italy and 3\% in France). Moreover, it is worth noting that the importance of this shock has the tendency to increase over time. With regard to the real wage $w$, it accounts for about $1-3 \%$ of

\begin{tabular}{|c|c|c|c|c|c|c|c|}
\hline \multicolumn{8}{|c|}{ Variance decomposition of TFP - Italy } \\
\hline 0 & 0.01 & $100 \%$ & $0 \%$ & $0 \%$ & $0 \%$ & $0 \%$ & \\
\hline 5 & 0.02 & $79 \%$ & $15 \%$ & $2 \%$ & $3 \%$ & $1 \%$ & Table 1. \\
\hline 10 & 0.03 & $70 \%$ & $17 \%$ & $8 \%$ & $4 \%$ & $1 \%$ & Percentage values \\
\hline
\end{tabular}

Asymmetries in the euro area and TFP growth

\section{3}

\begin{tabular}{rrrrrrrr}
\hline \multicolumn{2}{l}{$\begin{array}{l}\text { Variance decomposition of TFP - Germany } \\
\text { Period }\end{array}$} & Stan. Error & $a$ & $z$ & $r$ & $e$ & $w$ \\
\hline 0 & 0.01 & $100 \%$ & $0 \%$ & $0 \%$ & $0 \%$ & $0 \%$ & \\
5 & 0.02 & $85 \%$ & $6 \%$ & $3 \%$ & $4 \%$ & $2 \%$ & Table 2. \\
10 & 0.03 & $76 \%$ & $14 \%$ & $2 \%$ & $5 \%$ & $3 \%$ & Percentage values \\
\hline
\end{tabular}

\begin{tabular}{rrrrrrrr}
\hline \multicolumn{2}{l}{$\begin{array}{l}\text { Variance decomposition of TFP - France } \\
\text { Period }\end{array}$} & Stan. Error & $a$ & $z$ & $r$ & $e$ & $w$ \\
\hline 0 & 0.01 & $100 \%$ & $0 \%$ & $0 \%$ & $0 \%$ & $0 \%$ & \\
5 & 0.02 & $78 \%$ & $16 \%$ & $1 \%$ & $2 \%$ & $3 \%$ & Table 3. \\
10 & 0.03 & $72 \%$ & $22 \%$ & $1 \%$ & $3 \%$ & $2 \%$ & Percentage values \\
\hline
\end{tabular}


JES

48,5

964

the TFP variances in Italy, Germany and France. Altogether, after ten years, the shocks have an impact on TFP volatility of about $30 \%$ in Italy, $24 \%$ in Germany and $28 \%$ in France. Obviously, the ordering of the variables can affect the FEVD. However, our results do not significantly change using a different ordering of the variables in the model.

\section{Conclusions}

TFP growth has been lagging in euro-area countries, in particular in Italy, since at least the early 2000s. In all countries TFP has decelerated since 2008, starting to recover only in recent years. Given the importance of TFP growth for economic development, understanding the drivers of cross country differences in its growth should be at the top of the policy agenda for every government. In this paper we have shown how the asymmetric path of TFP between the three main European countries - Italy, Germany and France - can be traced back to four main sources. To address the point, we use macro data to track the aggregate effects of labor and capital misallocation over time across these countries. We assume the existence of four types of disturbances generating TFP changes. These disturbances can have permanent and transitory effects. To shape our view, we have used a labor market model in open economy with technological progress. Then, we have tested its predictions by means of a VAR model for the three European countries under investigation over the period 1983-2017. We get several results.

First, the empirical results show that capital misallocation and labor misallocation can negatively affect TFP in the long run. In other words, TFP has a positive relationship with price changes also in the long run, while it may be biased along the cycle because of price stickiness.

Second, we detect a positive long-run relationship between TFP and real exchange rate. This outcome strengthens the supply-side view of the relationship between productivity and real exchange rate according to which a hard currency can often induce firms (and policymakers) to update technology and knowledge in order to recover productivity and competitiveness in the long run. However, our findings also suggest that the significant increases in the TFP due to a (one standard deviation) shock to the real exchange rate affect different countries with different magnitude and different timing. Nevertheless, our analysis suggests that the divergence in TFP path in the eurozone can be, at most, only partially explained by the hard exchange rate policy.

Rather, as argued in our paper, the observed divergences in TFP can be traced back to the misallocation effects attributable to the decrease of real interest rate and real wages, together with the increasing labor flexibility. To sum up, to the extent that euro-area economies are far from being frictionless, economic policies that could reduce the cyclical and structural distortions identified here may have strong effects on aggregate TFP growth through a more efficient reallocation of production factors.

As said earlier, the present labor market model is stylized and may not capture all of the details of reality. We believe that further work is needed to refine our specification and the underlying shocks. We have in mind some specific extensions. The analysis should be extended to a larger number of countries. Technology progress could be proxied using different variables, as the R\&D expenditure or the number of patents. Micro data, for specific sectors and industries, can improve the quality of the empirical investigation. Of course, we aim at extending the present setup in these directions. However, we believe that the present setup can be helpful to reflect critically on the nodes at the core of the productivity slowdown and asymmetries in the eurozone. The aim is to implement renewed policies in order to favor economic growth, convergence and stability in the euro area.

\section{Notes}

1. Singapore, for example, had a long period of deliberate appreciation of the exchange rate with a stated intention of forcing competitive productivity increases ( $\mathrm{Lu}$ and $\mathrm{Yu}, 1999)$. 
2. Following AMECO's nomenclature and codes, we use the following series: total factor productivity (ZVGDF); real long-term interest rates (ILRV); real effective exchange rate (XUNRQ); real compensation per employee (RWCDV). Series in real terms are all deflated using the GDP deflator.

3. The OECD statistics clarify that "a job may be regarded as temporary if it is understood by both employer and the employee that the termination of the job is determined by objective conditions such as reaching a certain date, completion of an assignment or return of another employee who has been temporarily replaced. In the case of a work contract of limited duration the condition for its termination is generally mentioned in the contract. To be included in these groups are: (1) persons with a seasonal job, (2) persons engaged by an employment agency or business and hired out to a third party for the carrying out of a 'work mission' (unless there is a work contract of unlimited duration with the employment agency or business), (3) persons with specific training contracts" (OECD.stat).

4. The Incidence of Permanent Employment (15-24) is from the LFS Dataset - Employment by Permanency (Dataset Level Metadata TEMP_I) of the OECD. We employ the 15-24 subset because it is the index that better captures the legislative change in the labor market legislation for a sufficiently long timeframe (1983-2017 in our sample). Actually, many OECD countries have embarked on reforms to reform the labor market, but in practice, most of the reforms have mainly affected temporary contracts for young workers. Note that the use of the overall group of workers (15-64) does not change the main results of our analysis since the two series are strongly correlated.

5. On the empirical ground, while TFP is directly employed in our model, our choice of using the incidence of temporary employment ITE on total employment to measure (the effects of) changes in labor regulation may appear less clear, instead of using the Employment Protection Legislation Index (EPL) computed by OECD. This choice is determined by the fact that during the period under consideration, the EPL decreases steadly in all countries, but changes are discontinuous and cannot be efficiently employed in time series analyses. To overcome this problem, the incidence of temporary employment for young workers is used to proxy the effect of changes in labor regulation. Precisely, we observe that in a more (less) flexible labor market, the share of temporary employment is higher (lower). Figure 1 supports this interpretation by displaying the remarkable increase in the share of temporary young workers (our $z$ in the main text) in Italy, Germany and France during the same period in which the EPL index decreased.

\section{References}

Acemoglu, D. (1998), "Why do new technologies complement skills? Directed technical change and wage inequality", Quarterly Journal of Economics, Vol. 113 No. 4, pp. 1055-1089.

Azariadis, C. and Kaas, L. (2016), "Capital misallocation and aggregate factor productivity", Macroeconomic Dynamics, Vol. 20 No. 2, pp. 525-543.

Bagnai, A. and Mongeau-Ospina, C.A. (2017), "Neoclassical versus Kaldorian explanations of Southern Europe's productivity slowdown”, Acta Oeconomica, Vol. 67 No. s1, pp. 113-135.

Bartelsman, E.J., Gautier, P.A. and De Wind, J. (2016), "Employment protection, technology choice, and worker allocation”, International Economic Review, Vol. 57 No. 3, pp. 787-826.

Bassanini, A., Nunziata, L. and Venn, D. (2009), "Job protection legislation and productivity growth in OECD countries", Economic Policy, Vol. 24 No. 58, pp. 349-402.

Benigno, G. and Fornaro, L. (2014), "The financial resource curse", The Scandinavian Journal of Economics, Vol. 116 No. 1, pp. 58-86.

Bentolila, S. and Bertola, G. (1990), "Firing costs and labor demand: how bad is eurosclerosis?”, The Review of Economic Studies, Vol. 57 No. 3, pp. 381-402.

Blanchard, O. (2013), Blanchard: Macroeconomics, Pearson Higher, New York City.

Blanchard, O. and Wolfers, J. (2000), "The role of shocks and institutions in the rise of European unemployment: the aggregate evidence”, The Economic Journal, Vol. 110 No. 462, pp. C1-C33. 
JES

48,5

966

Cacciatore, M. and Fiori, G. (2016), "The macroeconomic effects of goods and labor markets deregulation", Review of Economic Dynamics, Vol. 20, pp. 1-24.

Calcagnini, G., Giombini, G. and Travaglini, G. (2018), "A Schumpeterian model of investment and innovation with labor market regulation", Economics of Innovation and New Technology, Vol. 27 No. 7, pp. 628-651.

Capasso, S., Napolitano, O. and Viveros Jiménez, A.L. (2019), "The long-run interrelationship between exchange rate and interest rate: the case of Mexico", Journal of Economics Studies, Vol. 46 No. 7 , pp. 1380-1397.

Carlin, W. and Soskice, D. (2014), Macroeconomics: Institutions, Instability, and the Financial System, OUP Oxford, Oxford.

Cette, G., Fernald, J. and Mojon, B. (2016), "The pre-Great Recession slowdown in productivity”, European Economic Review, Vol. 88, pp. 3-20.

Clements, M.P. and Hendry, D.F. (1995), "Forecasting in cointegrated systems", Journal of Applied Econometrics, Vol. 10 No. 2, pp. 127-146.

Dew-Becker, I. and Gordon, R.J. (2008), The Role of Labor Market Changes in the Slowdown of European Productivity Growth, National Bureau of Economic Research, Cambridge, Massachusetts, No. w13840.

Engle, R.F. and Yoo, B.S. (1987), "Forecasting and testing in co-integrated systems", Journal of Econometrics, Vol. 35 No. 1, pp. 143-159.

Gopinath, G., Kalemli-Özcan, Ş., Karabarbounis, L. and Villegas-Sanchez, C. (2017), "Capital allocation and productivity in South Europe", Quarterly Journal of Economics, Vol. 132 No. 4, pp. 1915-1967.

Griffith, R. and Macartney, G. (2014), "Employment protection legislation, multinational firms, and innovation", The Review of Economics and Statistics, Vol. 96 No. 1, pp. 135-150.

Harris, R.G. (2001), "Is there a case for exchange rate induced productivity changes?", Centre for International Economic Studies, Discussion Paper No. 0110, pp. 1-44.

Hoffman, D.L. and Rasche, R.H. (1996), "Assessing forecast performance in a cointegrated system", Journal of Applied Econometrics, Vol. 11 No. 5, pp. 495-517.

Kaas, L. (2016), "Public debt and total factor productivity", Economic Theory, Vol. 61 No. 2, pp. 309-333.

Kaldor, N. (1966), Causes of the Slow Rate of Economic Growth of the United Kingdom: An Inaugural Lecture, Cambridge University Press, Cambridge.

Lane, P.R. (2006), "The real effects of European monetary union", The Journal of Economic Perspectives, Vol. 20 No. 4, pp. 47-66.

Layard, R., Nickell, S. and Jackman, R. (1997), Unemployment: Macroeconomic Performance and the Labor Market, Oxford University Press, Oxford.

Lu, D. and Yu, Q. (1999), "Hong Kong's exchange rate regime: lessons from Singapore”, China Economic Review, Vol. 10 No. 2, pp. 122-140.

Melitz, M.J. (2003), "The impact of trade on intra-industry reallocations and aggregate industry productivity", Econometrica, Vol. 71 No. 6, pp. 1695-1725.

Naka, A. and Tufte, D. (1997), "Examining impulse response functions in cointegrated systems", Applied Economics, Vol. 29 No. 12, pp. 1593-1603.

Nickell, S. and Layard, R. (1999), "Labor market institutions and economic performance", Handbook of Labor Economics, Vol. 3, pp. 3029-3084.

Ostry, S. (1998), "Technology, productivity and the multinational enterprise", Journal of International Business Studies, Vol. 29 No. 1, pp. 85-99.

Pessoa, J.P. and Van Reenen, J. (2014), "The UK productivity and jobs puzzle: does the answer lie in wage flexibility?", The Economic Journal, Vol. 124 No. 576, pp. 433-452. 
Porter, M.E. (1990), The Competitive Advonioge of Notions. Harvard Business Review, Boston, Massachusetts.

Reis, R. (2013), The Portuguese Slump and Crash and the Euro Crisis, No. W19288, National Bureau of Economic Research, Cambridge, Massachusetts.

Rodrik, D. (2008), "The real exchange rate and economic growth", Brookings Papers on Economic Activity 2008, Vol. 2, pp. 365-412.

Romer, P.M. (1994), “The origins of endogenous growth”, The Journal of Economic Perspectives, Vol. 8 No. 1, pp. 3-22.

Saltari, E. and Travaglini, G. (2006), "The effects of future financing constraints on capital accumulation: some new results on the constrained investment problem", Research in Economics, Vol. 60 No. 2, pp. 85-96.

Saltari, E. and Travaglini, G. (2009), "Productivity slowdown puzzle. Technological and nontechnological shocks in the labor market", International Economic Journal, Vol. 23 No. 4, pp. 483-509.

Schumpeter, J.A. (1961), The Theory of Economic Development: An Inquiry into Profits, Capital, Credit, Interest, and the Business Cycle, Harvard University Press.

Sims, C.A. (1980), "Macroeconomics and reality", Econometrica: Journal of the Econometric Society, Vol. 48 No. 1, pp. 1-48.

Solow, R.M. (1957), "Technical change and the aggregate production function", The Review of Economics and Statistics, Vol. 39 No. 3, pp. 312-320.

Syverson, C. (2011), "What determines productivity?", Journal of Economic Literature, Vol. 49 No. 2, pp. 326-65.

Tomlin, B. and Fung, L. (2010), The Effect of Exchange Rate Movements on Heterogeneous Plants: a Quantile Regression Analysis, No. 2010, 25, Bank of Canada Working Paper.

Verdoorn, J.P. (1949), "On the factors determining the growth of labor productivity", Italian Economic Papers, Vol. 2, pp. 59-68.

\section{Corresponding author}

Giuseppe Travaglini can be contacted at: giuseppe.travaglini@uniurb.it

For instructions on how to order reprints of this article, please visit our website:

www.emeraldgrouppublishing.com/licensing/reprints.htm

Or contact us for further details: permissions@emeraldinsight.com 